\title{
VÁLLALATOK AZ INNOVÁCIÓS RENDSZERBEN
}

Az innovatív vállalkozások aránya egy-egy nemzetgazdaság megújulás- és versenyképességének fontos mérőszáma, melyet Európa-szerte kétévente rendszeresen megmérnek. A mutatószám a szakpolitikai vélemények artikulálásakor szívesen hivatkozott innovációs eredménytábla összesített indikátorában is megjelenik. A cikkben elemzett statisztikai adatok szerint a vállalkozási szektor K+F tevékenysége az Európai Unió országainak többségében egyre kevésbé, az innovációs rendszer funkcióinak egyes minőségi jellemzői pedig egyre inkább kapcsolatban vannak az innovatív vállalkozások arányával, ami hosszabb távon is hatással lehet mind a témakör kutatására, mind a várható elemzési hangsúlyokra. ${ }^{1}$

\section{Kulcsszavak: innovációs rendszer, vállalkozási K+F}

A z Eurostat ún. Közösségi Innovációs Felmérései (Community Innovation Survey, CIS) több, mint tíz éve mérik kontinensszerte az üzleti szektor innovációs tevékenységét, így mára viszonylag hosszabb idősoron követhető például az is, hogy változik-e érdemben a technológiai innovációt ${ }^{2}$ végrehajtó vállalkozások aránya. Ha megnézzük tíz év összesen öt felmérésének adatait, akkor ez a mutatószám nagyfokú stabilitást mutat Európa országainak körében, a relatív szórással mérhető ingadozása nem jelentős (1. ábra).

1. ábra

A technológiai innovációt végrehajtó vállalkozások aránya 2010-2012-ben és az arányszám relatív szórása a CIS mérésekben (\%)

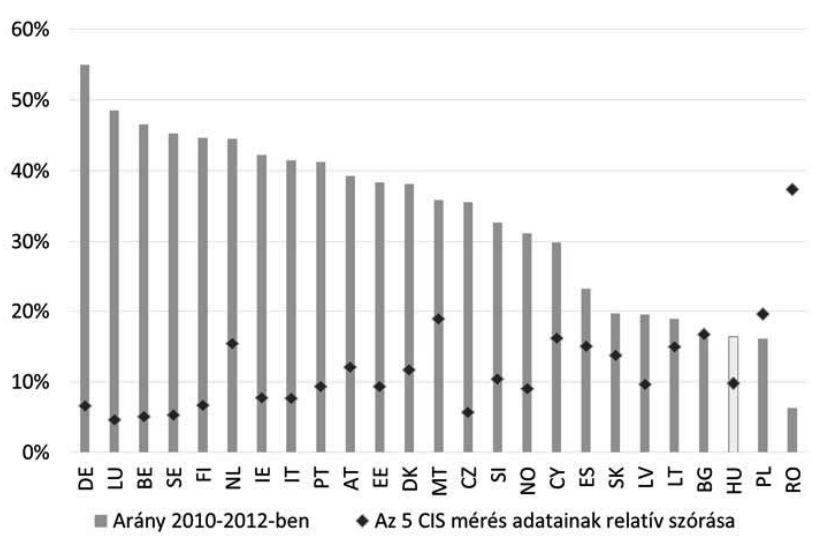

Megjegyzés: a 10 főnél többet foglalkoztató cégekre vonatkozó adatok. Forrás: Eurostat, illetve saját számítások

Ugyanebben az időszakban, például a magyar esetben is, a vállalkozási kutatási és fejlesztési tevékenység dinamikus felfutása tapasztalható: a 2. ábra együtt mutatja az innovációs és a $\mathrm{K}+\mathrm{F}$ tevékenységek legismertebb statisztikai mutatóit.

$\mathrm{S}$ bár az innováció és a kutatás-fejlesztés teljesen eltérő koncepciók, az üzleti szektor esetében azt várnánk, hogy a technológiai innovációs és a $\mathrm{K}+\mathrm{F}$ tevékenységek mutatói a makrogazdaság szintjén nagyjából együtt mo- zognak, vagy legalábbis szisztematikus elválásuk kivételes esetben fordul elö. Márpedig a 2. ábra mutatói közötti olló nemcsak a magyar, hanem a belga, bolgár, cseh, dán, német, észt, ír, spanyol, osztrák, lengyel, szlovén, olasz, litván, portugál, román, norvég gazdaságok esetében is nyílni látszik, azaz sok országban az üzleti szektor kutatás-fejlesztése más makrofejlődési pályán van, mint a technológiai innovációik.

2. ábra

A technológiai innovációt végrehajtó vállalkozások aránya és a vállalkozási szektor kutatás-fejlesztési ráfordításai a GDP arányában, Magyarországon

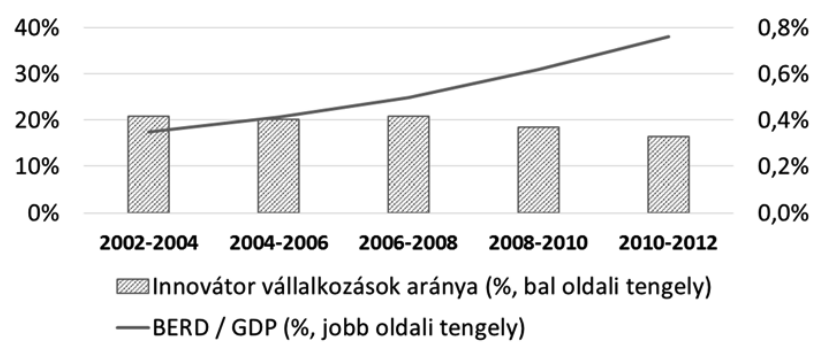

Megjegyzés: 1. A vállalkozások arányszáma a 10 főnél többet foglalkoztató cégekre vonatkozik. 2. BERD = Business Expenditures on R\&D: a vállalkozási szektor $K+F$ ráfordításai

Forrás: Eurostat

A többi európai ország esetében a mintázat kevésbé egyértelmü: az olló olykor záródik (Ciprus, Luxemburg), vagy stabil marad (Málta, Finnország, Svédország), illetve elöfordul az is, hogy hosszabb távú trend sem látható (Lettország, Szlovákia), mégis, adódik a kérdés, hogy mi állhat e jelenség hátterében.

Az egyik lehetséges magyarázat szerint a vállalkozási szektor $\mathrm{K}+\mathrm{F}$ tevékenysége - bár a vonatkozó GDP-arányos mutatószám a globális $\mathrm{K}+\mathrm{F}$ trendekre tekintettel továbbra is kiemelt figyelemre érdemes - azért válik el az innovációs folyamatoktól, mert más, a K+F-en kívül eső tényezők szerepe felértékelődik. Ezeknek a tényezőknek a feltárására az alábbiakban az innováció kutatásának egyre in- 
kább előtérbe kerülő rendszerszemléletű megközelítéseinek ${ }^{3}$ segítségével tettem kísérletet. Elsőként az innovációs rendszerek fogalmát, föbb típusait és funkcióit tekintem át, mivel az innovációs rendszerszemlélet az egyik fontos, és talán leginkább elterjedt elméleti keretként ad magyarázatot az innovációk születésének valószínüségére és hatásaik kiterjedtségére. ${ }^{4}$ Ezután az innovációs rendszer funkcióinak összességének jellemzésére használt statisztikai adatok együttmozgását, majd az innovatív vállalkozások arányával való kapcsolatát mutatom be, rávilágítva arra, hogy ezek a mutatószámok - a fent idézett $\mathrm{K}+\mathrm{F}$ ráfordítási mutatóval ellentétben - egyre jobban együtt mozognak az innovátor vállalkozások arányával.

\section{Innovációs rendszerek és azok funkciói}

Az elméleti közgazdászok közül az innovációról mint a társadalmi-gazdasági fejlődés fő mozgatórugójáról, elsőként Schumpeter (1934) számolt be. Makroszemlélete a rendszerelmélet egyik előfutára is. A rendszerelméletek kiindulópontja, hogy a rendszer alkotóelemekből áll, amelyeknek tulajdonságai vannak, és a köztük levő kapcsolatok határozzák meg a rendszer egészének müködését (Meadows, 2008).

Az innovációs rendszer első meghatározása Freemanhez (1987) köthető. ${ }^{5}$ Megfogalmazásában az innovációs rendszer intézmények és szervezetek halmaza, amelyek együttesen és külön-külön is hozzájárulnak az új tudás és az új technológiák kifejlesztéséhez, alkalmazásához és terjesztéséhez. ${ }^{6}$ A nemzetgazdasági szintre vonatkozó első megfogalmazást követően, részben annak kritikájaként a szakirodalom számos innovációs rendszerkoncepciót jegyzett fel, köztük a technológiai, a regionális, az ágazati és a globális innovációs rendszerekét.?

A technológiai (innovációs) rendszer meghatározott gazdasági-iparági területen kapcsolatba lépő, a tudás létrehozásában, felhasználásában és terjedésében részt vevő szereplők dinamikus hálózata, amelyet sajátos intézményi infrastruktúra használata jellemez. A technológiai rendszerekre a tudás és a kompetenciák áramlása jellemző. A technológiai rendszerek kulcselemei a gazdasági kompetencia (az új üzleti lehetőségek fejlesztésének és kiaknázásának képessége), az erőforrások klaszteresedése (földrajzi és technológiai értelemben) és az intézményi infrastruktúra (szervezetek, melyek közvetlenül vagy közvetetten támogatják, ösztönzik, illetve szabályozzák az innovációs folyamatokat és a technológia elterjedését) ${ }^{8}$ A technológiai innovációs rendszer a technológiai-iparági fókusznak, a nemzeti határokon átnyúló jellegének és a technológia adaptálására és hasznosítására irányuló szemléletének köszönhetően különbözik a nemzeti innovációs rendszer koncepciótól (Carlsson - Stankiewicz, 1991).

A regionális innovációs rendszerben két alrendszer, a tudás hasznosító és kiaknázó alrendszer, illetve a tudás létrehozó és terjesztő alrendszer kapcsolatain van a hangsúly (Autio, 1998). Az előbbi elsősorban - de nem kizárólagosan - vállalatokból áll, az utóbbi különböző közszféra-intézményekből. A regionális innovációs rendszerben a külső - a nemzetközi és nemzeti intézmények és politi- kák, más regionális rendszerek részéről érkező - hatások szerepe sem elhanyagolható (Cooke et al., 1997).

$\mathrm{Az}$ iparág határainak meghatározása hagyományosan az alkalmazott technológiák, a kereslet, illetve a belépési korlátok segítségével történt, azaz egy iparágba tartozónak a hasonló technológiákat, hasonló termékekkel, hasonló piacokat kiszolgáló szereplőket tekinthetjük. Malerba (2002) innovációs rendszerszemléletű, az iparágra vonatkozó újszerű meghatározása szerint az ágazati innovációs rendszer termékek és különböző egyéni és intézményi szereplők halmaza, melyek között piaci és nem piaci kapcsolatok, illetve interakciók segítik a szóban forgó termékek megalkotását, termelését és értékesítését. A kapcsolatok és interakciók intézmények által befolyásolt kommunikációs, csere-, kooperációs folyamatok, verseny, illetve utasítások formáját öltik. Az ágazati rendszer változását a különböző alkotóelemek együttfejlődése, koevolúciója határozza meg, és a versenyszektoron kívüli szereplök hatása is lényeges. ${ }^{9}$

3. ábra

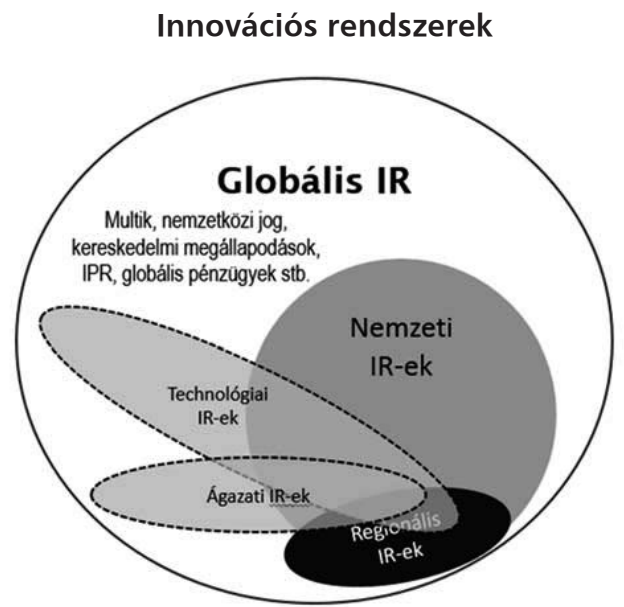

Megjegyzés: eltérés az eredetihez képest, hogy a RIR nemzeti határokon átnyúlóan lett ábrázolva.

Forrás: Asheim et al. (2011), egyszerüsítésekkel

A 3. ábrán látható, hogy a globális innovációs rendszer a cégek által hozzáférhető erőforrásokat és intézményeket foglalja magában, melyek kiépülését és fejlődését számos ország szervezetének interakciói alakítják (Spencer, 2003). A globális innovációs rendszer meghatározása összességében kevésbé kiforrott, amit Carlsson (2006) áttekintése megerősít: az innovációs rendszerek nemzetköziesedése csak kevés tudományos közleményben jelenik meg. ${ }^{10}$

A regionális, ágazati, technológiai és nemzeti innovációs rendszerek összetevői lényegében ugyanazok: ${ }^{11}$ különbségek az aggregálásokban (hogy ti. melyik intézményi szereplőt, illetve komponenst milyen szinten emelnek ki), illetve a hangsúlyokban (hogy ti. melyik összetevőnek tulajdonítanak nagyobb jelentőséget) mutatkoznak. A legfontosabb összetevők a következők: ${ }^{12}$

- a szereplők: az egyének (felhasználók), az értékláncok különböző szakaszait lefedő vállalatok, tanácsadók, felsőoktatási intézmények és kutatóintézetek, 
a kormányzat különböző szintjei, érdekképviseleti és civil szervezetek, finanszírozó szervezetek, szabványokkal és szellemi tulajdonvédelemmel foglalkozó szervezetek, könyvtárak, múzeumok, egészségügyi intézmények, szakemberek stb.,

- a szereplök formális és informális hálózatai: szabványosítással foglalkozó szervezetek és szerveződések, technológiai platformok, beszállítói hálózatok,
Az innovációs rendszer összetevőivel foglalkozó szakirodalom alapján (1. táblázat) a strukturális összetevők négy nagy csoportba sorolhatók (Wieczorek - Hekkert, 2012). Mindig feltehető az a kérdés, hogy egy adott összetevő egy adott innovációs rendszerben létezik-e, de ennél lényegesebb, hogy müködése/jelenléte milyen kvalitatív tulajdonságokkal bír.

1. táblázat

Az innovációs rendszer strukturális dimenziói, összetevői és tulajdonságaik

\begin{tabular}{|c|c|c|}
\hline Dimenzió & Összetevõ & Példa a kvalitatív tulajdonságra \\
\hline Szereplốk & $\begin{array}{l}\text { Civil társadalom, felhasználók } \\
\text { Cégek, finanszírozók } \\
\text { Tudásszervezetek (egyetemek stb.) } \\
\text { Kormányzat } \\
\text { Egyéb szereplők }\end{array}$ & $\begin{array}{l}\text { Kereslet ereje } \\
\text { Innovációmenedzsment-képesség } \\
\text { Tudás-elóallítás képessége } \\
\text { A kormányzás szakszerúsége } \\
\text { Illeszkedés az egyéb rendszerelemekhez }\end{array}$ \\
\hline Intézmények & $\begin{array}{l}\text { Kemény intézmények: törvények, szabályok, utasítások } \\
\text { Puha intézmények : szokások, rutinok, gyakorlatok, } \\
\text { hagyományok, magatartás, normák, várakozások }\end{array}$ & $\begin{array}{l}\text { A szabályozók életszerủsége, korszerứsége } \\
\text { A rutinok, szokások stb. tudást és } \\
\text { innovációt támogató karaktere }\end{array}$ \\
\hline Interakciók & $\begin{array}{l}\text { Hálózatosodott interakciók } \\
\text { Egyéni interakciók }\end{array}$ & $\begin{array}{l}\text { A szereplốk közötti formális és informális } \\
\text { interakciók erỗssége, minő̃sége és tartalma }\end{array}$ \\
\hline Infrastruktúra & $\begin{array}{l}\text { Fizikai infrastruktúra : mủtárgyak, eszközök, utak, } \\
\text { hidak, épületek, hálózatok, kikötốk } \\
\text { Tudás-infrastruktúra : szakértelem, know-how, } \\
\text { stratégiai információ, tacit/explicit tudás, oktatás } \\
\text { Pénzügyi infrastruktúra : támogatások, programok, } \\
\text { ösztöndíjak stb. }\end{array}$ & $\begin{array}{l}\text { A fizikai infrastruktúra színvonala } \\
\text { A tudás infrastruktúra illeszkedése a } \\
\text { gazdasági és társadalmi igényekhez } \\
\text { A pénzügyi támogatási rendszer } \\
\text { illeszkedése a gazdasági és társadalmi } \\
\text { igényekhez, illetve a támogató szakpolitika } \\
\text { szakszerűsége }\end{array}$ \\
\hline
\end{tabular}

Forrás: Wieczorek - Hekkert (2012). A kvalitatív tulajdonságok oszlop saját kifejtés.

szakmai tömörülések, fogyasztóvédelmi csoportok, különféle szakmai közösségek stb.,

- az intézmények mint szabályozók: a tudásfolyamatokra ható kultúra és összetevői, úgy is mint normák, törvények és egyéb szabályok, rutinok és magatartásformák,

- a politikai, makrogazdasági, társadalmi, technológiai és természeti környezet: a szereplők által egyénileg nem befolyásolható környezet lehetőségek és fenyegetések forrása,

- a fizikai és a kommunikációs infrastruktúra: mütárgyak, eszközök (gépek, berendezések stb.), explicit tudás és know-how, digitális és analóg csatornák elérhetősége, a média fejlettsége stb.,

- tényezőpiaci feltételek: tőke- és pénzpiaci szereplők és a finanszírozás elérhetősége, a munkaerő mennyisége és minősége, az energetikai, közlekedési, egészségügyi stb. hagyományos infrastruktúra,

- termékpiaci feltételek: vásárlóerő és kereslet, értékesítési hálózatok, kínált termékek és szolgáltatások összetétele.
A különböző innovációs rendszerek összetevői és tulajdonságaik ugyanis különböző minőségű müködést tesznek lehetővé, és, ahogy arra Wieczorek és Hekkert (2012) is felhívják a figyelmet, a rendszer szerkezetéböl önmagában nem, vagy csak kevéssé érthető meg a müködés hatékonysága, hatásossága. Ezért a folyamatokat, illetve a rendszer fő funkcióit érdemes elemezni: a funkciókat részletes és objektív, a nagyszámú innovációs rendszer irodalmat elemző módszertanra alapozva Hekkert et al. (2007) és Bergek et al. (2008) határozták meg..$^{13} \mathrm{Az}$ innovációs rendszer funkciói egészében lefedik a $\mathrm{K}+\mathrm{F}$ és innovációs folyamatokat is: ${ }^{14}$

1. a vállalkozás (entrepreneurship) stimulálása: a jól működő innovációs rendszer a régi folyamatokat, technológiákat, gondolkodásmódot megújítani képes vállalkozókat kísérletezésre csábítja,

2. tudásfejlesztés: a tudás és a tanulás - az új tudás fejlesztése, az új alkalmazások megtanulása és a régi tudás elfelejtése - a modern piacgazdaság kiemelten fontos eröforrásai,

3. a tudás terjedésének elösegitése formális és informális hálózatok segitségével, 
4. a választás elösegitése: az innovációs rendszer az információs aszimmetria, illetve a jövő bizonytalanságainak mérséklésével segítheti a hatékonyabb erőforrás-allokációt, illetve pozitív externáliákat,

5. a piacok fejlödésének és átalakulásának segitése: az innovációk kezdetben csak ritkán hordozzák mindazokat az előnyöket, amelyek később már nyilvánvalók, ezért az innovációs rendszer egyik fontos funkciója annak biztosítása, hogy a piaci potenciál minél inkább megmutatkozhasson,

6. erőforrások mobilizálása: pénzügyi és humán eröforrásokra egyaránt szükség van valamennyi tudásfolyamat hatékony menedzseléséhez,

7. legitimáció megteremtése: a változásokkal szembeni ellenállás leküzdéséhez szükség lehet az újdonságok felkarolására, hogy a kreatív rombolás folyamata hamarabb mehessen végbe.

Amennyiben az innovációs rendszer fó funkciói hatékonyak, az adott nemzetgazdaságban több és nagyobb hatású innovációra van esély, ami összességében hatással lehet arra is, hogy az EU Közösségi Innovációs Felmérésében végül milyen arányban bukkannak fel technológiai innovátor vállalatok. adatbázis), a felsőoktatási kutatók aránya az aktív népességben (Eurostat-adatok), a vállalatok közötti technológiai együttmüködés fejlettsége (IMD versenyképességi évkönyv adatai), a kereskedelmi akadályok leküzdésének nehézsége (WEF versenyképességi évkönyv adatai), az állampolgárok rugalmassága és adaptációs készsége (IMD versenyképességi évkönyv adatai) összességében megfelelően lefedni látszanak a fenti innovációs rendszerfunkciókat. Az adatok nem mind az öt, hanem csak az utolsó három CIS-méréshez (2008, 2010, 2012) igazíthatóan állnak rendelkezésre. Annak az évnek az adatait vettem figyelembe, amelyik évben a CIS-felmérés készült, azaz a három évet felölelő CIS-időszakok utolsó évének adatait és ugyanezt az eljárást követtem a vállalkozási $\mathrm{K}+\mathrm{F}$ ráfordítási adatok esetében.

Amennyiben az innovációs rendszer funkcióit többé-kevésbé lefedő proxy-változók és a technológiai innovációt végrehajtó vállalkozások között erősebb statisztikai összefüggés mutatkozik, mint a vállalkozási $\mathrm{K}+\mathrm{F}$ és a technológiai innovátor vállalkozások között, akkor megerősítést nyer az a sejtés, hogy a vállalkozási $\mathrm{K}+\mathrm{F}$ mellett más szempontok is fontosak a makrogazdasági szintű innovációs teljesítmény kibontakozásához.

\section{2. táblázat}

\begin{tabular}{|c|c|c|c|c|c|}
\hline & $\begin{array}{l}\text { Adófizetési } \\
\text { terhek }\end{array}$ & $\begin{array}{l}\text { Felsőoktatási } \\
\text { kutatók aránya }\end{array}$ & $\begin{array}{l}\text { A technológiai } \\
\text { együttmüködés } \\
\text { fejlettsége }\end{array}$ & $\begin{array}{l}\text { Kereskedelmi } \\
\text { akadályok }\end{array}$ & $\begin{array}{l}\text { Állampolgárok } \\
\text { rugalmassága }\end{array}$ \\
\hline & \multicolumn{5}{|c|}{2008} \\
\hline Adófizetési terhek (középvállalatok) & & $0,422^{*}$ & $0,532^{*}$ & 0,302 & 0,386 \\
\hline Felsőoktatási kutatók aránya & & 1 & 0,387 & 0,268 & 0,289 \\
\hline A technológiai együttműködés fejlettsége & & & 1 & $0,567^{* *}$ & 0,193 \\
\hline Kereskedelmi akadályok & & & & 1 & 0,204 \\
\hline \multirow[t]{2}{*}{ Állampolgárok rugalmassága } & & & & & 1 \\
\hline & \multicolumn{5}{|c|}{2010} \\
\hline Adófizetési terhek (középvállalatok) & & $0,441^{*}$ & $0,624^{* *}$ & 0,213 & 0,358 \\
\hline Felsőoktatási kutatók aránya & & 1 & 0,408 & 0,269 & 0,397 \\
\hline A technológiai együttműködés fejlettsége & & & 1 & 0,287 & $0,481^{*}$ \\
\hline Kereskedelmi akadályok & & & & 1 & 0,158 \\
\hline \multirow[t]{2}{*}{ Állampolgárok rugalmassága } & & & & & 1 \\
\hline & \multicolumn{5}{|c|}{2012} \\
\hline Adófizetési terhek (középvállalatok) & & $0,470^{*}$ & $0,594^{* *}$ & 0,326 & 0,344 \\
\hline Felsőoktatási kutatók aránya & & 1 & $0,523^{*}$ & 0,337 & 0,417 \\
\hline A technológiai együttműködés fejlettsége & & & 1 & 0,318 & $0,524^{*}$ \\
\hline Kereskedelmi akadályok & & & & 1 & 0,183 \\
\hline Állampolgárok rugalmassága & & & & & 1 \\
\hline
\end{tabular}

Jelölés: *95\%-os szignifikanciaszinten jelentős korreláció, **99\%-os szignifikanciaszinten jelentős korreláció Forrás: számítások a Világbank, az IMD és a WEF adatai alapján

\section{A funkciók és a vállalati K+F-teljesítmény összehasonlítása}

Az innovációs rendszerfunkciók hatékonyságának jellemzésére ún. proxy-változók gyüjthetők össze. A középvállalatok adófizetési terhei (Világbank Doing Business
Az összegyűjtött mutatószámok között van ugyan korreláció, de ez nem egységesen erős és időben is mutatkoznak eltérések (2. táblázat).

Ugyanakkor ha fökomponens-elemzést végzünk, a mérőszámok mindhárom időszak esetében egyetlen főkomponensbe állnak össze, és az időben előrehaladva a mutatószá- 
mok egyre inkább együtt mozognak. És bár a kereskedelmi akadályokra vonatkozó mutatószám valamelyest kivételt jelent, ez a mutató is jelentős összetevője a fökomponensnek mind 2008-ban, mind 2012-ben. Ennél is lényegesebb, hogy a főkomponens által magyarázott szórás lassan nő, rendre 49,5\%, 50,8\% és 54,5\% (3. táblázat).

\section{3. táblázat}

A főkomponensek és az innovációs rendszer funkcióit jellemző egyedi mérőszámok korrelációi

\begin{tabular}{llll}
\hline & $\mathbf{2 0 0 8}$ & $\mathbf{2 0 1 0}$ & $\mathbf{2 0 1 2}$ \\
\hline Adófizetési terhek (középvállalatok) & 0,777 & 0,793 & 0,801 \\
Felsőoktatási kutatók aránya & 0,681 & 0,744 & 0,806 \\
A technológiai együttműködés fejlettsége & 0,797 & 0,819 & 0,826 \\
Kereskedelmi akadályok & 0,694 & 0,477 & 0,556 \\
Állampolgárok rugalmassága & 0,538 & 0,680 & 0,665 \\
\hline \multicolumn{1}{c}{ A fókomponens által magyarázott szórás } & $49,5 \%$ & $50,8 \%$ & $54,5 \%$
\end{tabular}

Forrás: számítások a Világbank, az IMD és a WEF adatai alapján alacsony száma miatt - kísérleti munkának tekinthető, ugyanakkor az a tény, hogy négy különböző adatbázisból vett adatok segítségével a vizsgálni kívánt jelenség illusztrálható, és időben előre haladva a jelenség erősödik, bizakodásra ad okot az innovációs rendszer minőségi jellegzetességeivel foglalkozó jövőbeli kutatásokhoz. A két legfontosabb tanulság így összegezhető:

1. A vállalkozási $\mathrm{K}+\mathrm{F}$ ráfordítások - vélhetően egy sor, itt nem elemzett jelenségnek ( $\mathrm{pl}$. a globális értékláncok, benne a $\mathrm{K}+\mathrm{F}$ feladatok aprózódásának) is köszönhetően - az európai országok egy jelentős részénél egyre kevésbé látszik kapcsolatban lenni az adott ország vállalkozásainak innovációs teljesítményével, vagy legalábbis azzal a mutatószámmal, amelyet makroszinten ennek jellemzésére gyakran használnak. Előfordulhat az is, hogy az innováció egyre szélesebb körben való, viszonylagosan térítésmentesen történő megvalósításának terjedése (von Hippel (2005) fordulatával: demokratizálódása) azt

Az innovációs rendszer funkcióit magyarázó főkomponens kapcsolata a technológiai innovátor vállalkozások arányával és a vállalkozási szektor kutatás-fejlesztési ráfordításaival

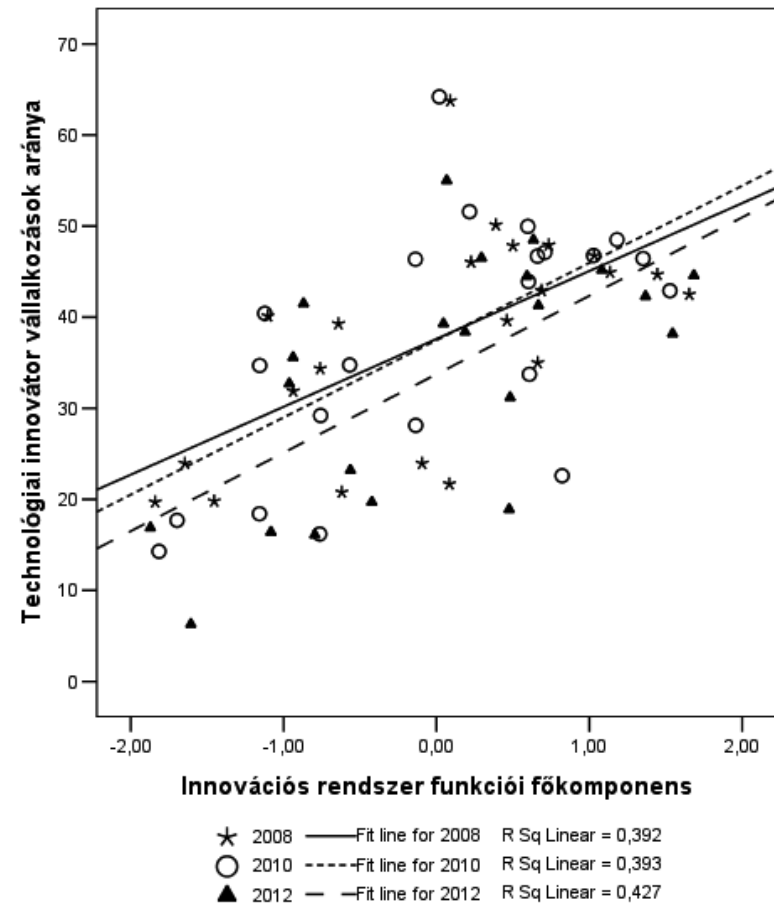

O 2010 -.---fit line for 2010 R Sq Linear $=0,393$

A 2012 - -Fit line for 2012 R Sq Linear $=0,427$

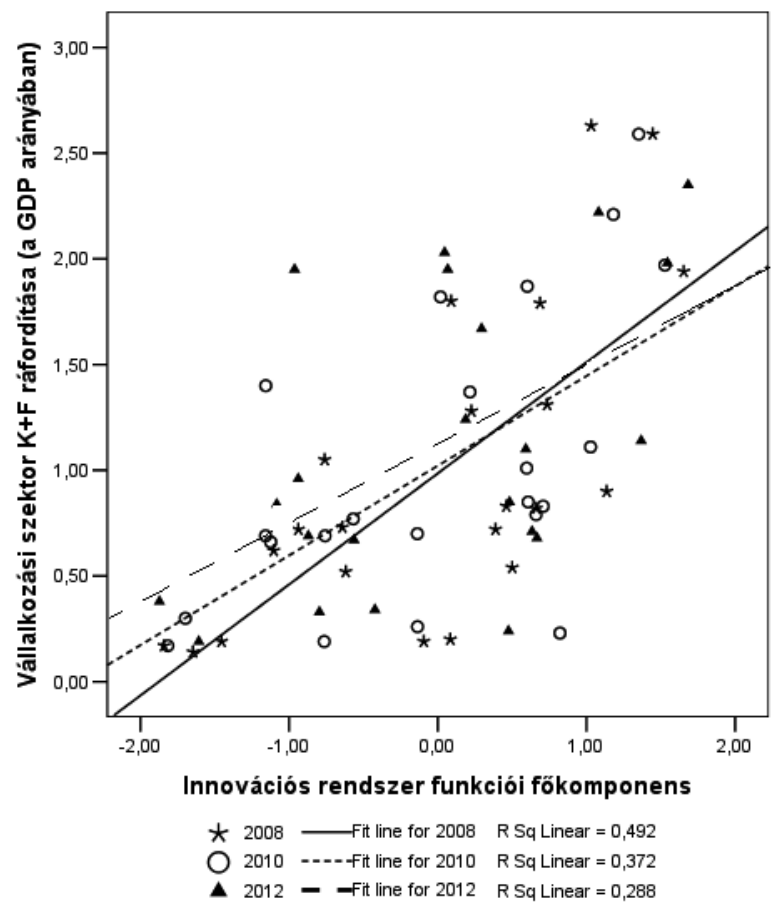

Forrás: számítások az Eurostat, a Világbank, az IMD és a WEF adatai alapján

is okozza, hogy ma már a kutatás-fejlesztési tevékenységeknek a korábbiaknál jelentősebb része nem jelenik meg a hivatalos statisztikákban.

2. Az innovációs rendszer funkcióinak együttes müködésének elemzése mindenképp lényegesebb lehet az innovációs jelenségek dinamizálásának megértése szempontjából, mint az egy-egy - mégoly lényeges - kiragadott mutatószám által leírható dinamikák. 
Záró gondolatként ha a freemani meghatározást az újabb kutatási eredmények alapján korszerüsítjük, akkor az innovációs rendszer megadható úgy, mint ,intézmények, szervezetek és személyek halmaza a magán- és a közszférában, amelyek kompetenciái, tevékenységei és interakciói tudás, készségek, kapcsolódó „,mütárgyak”, valamint technológiák létrehozását kezdeményezik, azokat megalkotják, importálják, tárolják, módositják, alkalmazzák és terjesztik". A bemutatott, a 10 éves magyar EU-tagság időszakát lényegében lefedő számítások alapján az egyre inkább tudásvezérelt gazdaságok korában inkább érdemesnek látszik ebben a gondolkodási keretben keresni a választ az áhított felzárkózás mikéntjére, mintsem bízni az egy vagy néhány mutatószám növelésével ${ }^{15}$ elérhető teljesítményjavulásban.

\section{Jegyzetek}

1 A cikk a Bolyai János Kutatási Ösztöndíj támogatásával készült.

2 A felmérés meghatározása szerint a technológiai innovációt végrehajtó vállalkozás új terméket vezetett be a piacra és/vagy megújította gyártási (szolgáltatási) eljárásait. Az újabb CIS-felmérések az innováció fogalmát kiterjesztően, például a marketing- és szervezési innovációkra is tekintettel használják, ám tíz év távlatában a technológiai innovátor vállalkozások adatai állnak rendelkezésre.

3 A rendszerszemléletű innovációkutatás legjelentősebb mérföldköveinek az áttekintése is meghaladná e tanulmány kereteit. Ebben a cikkben is csak a kutatáshoz legszükségesebb információkat közlöm. Az érdeklődők lényeges elágazásokat, illetve részleteket ismerhetnek meg Vas (2014) értekezésében, valamint Vas és Bajmócy (2012) az innovációs rendszerelmélet történeti fejlödését is áttekinti.

4 A hármas csavarmodell (triple helix, lásd: Etzkowitz és Leydesdorff 2000) egy másik megközelítés, de rokonítható a gyémántmodell (Porter (1990)), illetve az evolucionista közgazdaságtan (Hodgson, 2002; Kiss, 2005) is.

5 Vas (2014) kiemeli, hogy Friedrich List 1841-es „A politikai gazdaságtan nemzeti rendszere” című munkája akár a „Nemzeti innovációs rendszer" címet is kaphatta volna. De List eszméinek korai magyar összegzései is ismertek (lásd pl. Horn, 1942).

6 A 90-es évek végére a technológiai változás mértékadó kutatói a Nemzeti Innovációs Rendszer (NIR) meghatározását tovább finomították (OECD, 1997, 10. o.). A freemani definíció 25 éves évfordulójának tiszteletére magyar nyelvü kötet is megjelent (Inzelt - Bajmócy, 2013).

7 Vannak érvek amellett, hogy elméleti szempontból a nemzeti innovációs rendszer a leglényegesebb, lásd Lundvall (2007) érvelését.

8 Itt érdemes említeni az ökoszisztéma fogalmát, ugyanis eredeti megfogalmazásában (Moore, (1993) a vállalati ökoszisztéma a technológiai innovációs rendszer előfutárának (illetve alhalmazának) tekinthető, mivel lazán, közös technológia és tudás mentén szerveződő, versengő és együttműködő, innováló vállalatok csoportjára utal. Azóta az innovációs ökoszisztéma kifejezés pl. regionális csomóponti hangsúlyt is kapott, és természetesen megjelentek a további intézményi szereplők is a vállalatok mellett.

$9 \mathrm{Az}$ ágazati innovációs rendszer koncepció jól összhangba hozható Porter (1985) értéklánc-koncepciójával.

10 Kivétel pl. Pietrobelli és Rabellotti (2011) cikke, melyben globális értékláncok és az innovációs rendszer kapcsolatát vizsgálják.

11 A bizonyítás meghaladja a cikk kereteit.

$12 \mathrm{Az}$ összetevök áttekintéséhez kiindulópontot Bergek et al. (2008) cikke, illetve az OECD (1998) kiadványa jelentett.

13 Majd átvette Wieczorek és Hekkert (2012) is

14 A fó funkcióknak a cikkben közölt tartalmi magyarázata saját kifejtés.

15 Havas (2014) - több, az itt kifejtettekhez kapcsolódó témakör mellett - arra is felhívja a figyelmet, hogy a rendszerszemléletü mérésnek szánt innovációs eredménytábla egészében komoly elméleti hiányosságok is mutatkoznak, amiből az következik, hogy a koncepcionális alapok végiggondolása nélkül még a sok méröszám együttes figyelemmel követése és a javításukra való közvetlen törekvés sem feltétlenül hoz eredményt.

\section{Felhasznált irodalom}

Asheim, B. T. - Smith, H. L. - Oughton, C. (2011): Regional innovation systems: theory, empirics and policy. Regional Studies, Vol. 45 (7), 875-891. o. http://dx.doi. org/10.1080/00343404.2011.596701
Autio, E. (1998): Evaluation of RTD in regional systems of innovation. European Planning Studies, Vol. 6 (2), 131-140. o. http://dx.doi. org/10.1080/09654319808720451

Bergek, A. - Jacobsson, S. - Carlsson, B. - Lindmark, S. - Rickne, A. (2008): Analyzing the functional dynamics of technological innovation systems: A scheme of analysis. Research Policy, Vol. 37, 407-429. o. http://dx.doi.org/10.1016/j.respol.2007.12.003

Carlsson, B. (2006): Internationalization of innovation systems: A survey of the literature. Research Policy, Vol. 35 (1), 229-258. o. http://dx.doi.org/10.1016/j. respol.2005.08.003

Carlsson, B. - Stankiewicz, R. (1991): On the Nature, Function, and Composition of Technological Systems. Journal of Evolutionary Economics Vol. 1, 93118.o. http://dx.doi.org/doi: 2010.1007/BF01224915

Cooke, P. - Uranga, M.G. - Etxebarria, G. (1997): Regional innovation systems: Institutional and organisational dimensions. Research Policy, Vol. 26, 475-491.o. http://dx.doi.org/10.1016/S00487333(97)00025-5

Etzkowitz, H. - Leydesdorff, L. (2000): The dynamics of innovation: from National Systems and "Mode 2 " to a Triple Helix of university-industry-government relations. Research Policy Vol. 29, 109-123.o. http://dx.doi.org/10.1016/S0048-7333(99)00055-4

Freeman, C. (1987): Technology Policy and Economic Performance: Lessons from Japan. London, New York: Pinter Publishing

Havas A. (2014): Mit mér(j)ünk? Az innováció értelmezései - szakpolitikai következmények. Közgazdasági Szemle, Vol. 61 (9), 1022-1059. o.

Hekkert, M. P. - Suurs, R. A. A. - Negroa, S. O. - Kuhlmann, S. - Smits, R. E. H. M. (2007): Functions of innovation systems: A new approach for analysing technological change. Technological Forecasting and Social Change, Vol. 74 (4), 413-432. o. http:// dx.doi.org/10.1016/j.techfore.2006.03.002

von Hippel, E. (2005): Democratizing Innovation. Cambridge, MA: MIT Press

Hodgson, G. M. (szerk.) (2002): A Modern Reader in Institutional and Evolutionary Economics. Cheltenham: Edward Elgar

Horn J. (1942): A közgazdaságtan nemzeti rendszere. Szeged: Szeged Városi Nyomda és Könyvkiadó Részvénytársaság

Inzelt A. - Bajmócy Z. (szerk.) (2013): Innovációs rendszerek: Szereplők, kapcsolatok és intézmények. Szeged: JATE Press

Kiss J. (2005): Az innováció és a technológiai fejlödés elmélete az evolucionista közgazdaságtanban. Műhelytanulmány. Budapest: Budapesti Corvinus Egyetem Vállalatgazdaságtan Intézet, http://edok. lib.uni-corvinus.hu/88/1/Kiss59.pdf

Lundvall, B. A. (2007): National Innovation Systems Analytical Concept and Development Tool. Industry and Innovation, Vol. 14 (1), 95-119. o. http://dx.doi. org/10.1080/13662710601130863 
Malerba, F. (2002): Sectoral systems of innovation and production. Research Policy, Vol 31, 247-264. o. http:// dx.doi.org/10.1016/S0048-7333(01)00139-1

Meadows, D. H. (2008): Thinking in Systems. A Primer. White River Junction Vermont: Chelsea Green Publishing

Moore, J. F. (1993): Predators and prey: The new ecology of competition. Harvard Business Review, Vol. 71 (3), 75-83.0.

OECD (1997): National Innovation Systems. Paris: OECD OECD (1998): Technology, productivity and job creation. Paris: OECD

Pietrobelli, C. - Rabellotti, R. (2011): Global Value Chains Meet Innovation Systems: Are There Learning Opportunities for Developing Countries? World Development, Vol. 39 (7), 1261-1269. o. http://dx.doi.org/10.1016/j.worlddev.2010.05.013

Porter, M. E. (1985): Competitive Advantage: Creating and Sustaining Superior Performance. New York: The Free Press

Porter, M. E. (1990): The Competitive Advantage of Nations. New York: The Free Press

Schumpeter, J. (1934): The Theory of Economic Development: An Inquiry into Profits, Capital, Credit, Interest, and the Business Cycle. Cambridge, MA: Harvard University Press. Magyarul: A gazdasági fejlődés elmélete. Vizsgálódás a vállalkozói profitról, a tőkéről, a hitelről, a kamatról és a konjunktúraciklusról. Budapest: Közgazdasági és Jogi Könyvkiadó, 1980, 320 o.

Spencer, J. W. (2003): Firms' Knowledge-Sharing Strategies in the Global Innovation System: Empirical Evidence from the Flat Panel Display Industry. Strategic Management Journal, Vol. 24, 217-233. o. http://dx.doi. org/ doi:10.1002/smj.290

Vas Zs. - Bajmócy Z. (2012): Az innovációs rendszerek 25 éve. Szakirodalmi áttekintés evolúciós közgazdaságtani megközelítésben. Közgazdasági Szemle, Vol. 59 (11), 1233-1256. o.

Vas Zs. (2014): Tudásintenzív szektorális innovációs rendszerek a Dél-Alföld régióban. Doktori értekezés. Szeged: Szegedi Tudományegyetem, Gazdaságtudományi Kar, Közgazdaságtani Doktori Iskola

Wieczorek, A. J. - Hekkert, M. P. (2012): Systemic instruments for systemic innovation problems: A framework for policy makers and innovation scholars. Science and Public Policy, Vol. 39, 74-87. o. https://doi.org/10.1093/ scipol/scr008 